\title{
Increased leptin and tumour necrosis factor $\alpha$ per unit fat mass in hypopituitary women without growth hormone treatment
}

\author{
Birgitta Bülow, Bo Ahrén and Eva Marie Erfurth \\ Department of Medicine, Lund University, Lund, Sweden \\ (Correspondence should be addressed to Birgitta Bülow, Department of Diabetology and Endocrinology, University Hospital, S-221 85 Lund, Sweden)
}

\begin{abstract}
Background: The adipocyte products, leptin and tumour necrosis factor (TNF) $\alpha$, are associated with atherosclerotic diseases and may be factors contributing to the enhanced cardiovascular risk in hypopituitary patients with growth hormone $(\mathrm{GH})$ deficiency.

Objective: To investigate whether leptin and TNF $\alpha$ are increased in a group of hypopituitary women previously found to have increased cardiovascular morbidity, and to compare them with matched individuals of the same sex and age and with similar body composition.

Design and Patients: Thirty-three GH-deficient women with a median age of 64 years (range 39-77 years) were investigated cross-sectionally. The patients were compared with 33 controls matched for sex, age, smoking habits, educational level and residence.

Methods: Body composition was measured by bioimpedance analysis. Fasting concentrations of leptin, TNF $\alpha$ and insulin were analysed in patients and controls.

Results: There was no significant difference in body mass index or fat mass between patients and controls (both $P \geq 0.4$ ). Serum leptin did not differ significantly between patients and controls. However, when serum leptin concentrations were expressed per kilogram fat mass, the patients had significantly greater concentrations $(P=0.01)$. Serum TNF $\alpha$ and TNF $\alpha$ per kilogram fat mass were also significantly greater in the patients (both $P=0.001$ ). In contrast, serum insulin did not differ significantly between patients and controls. In the patients, serum leptin concentrations correlated positively with kilogram fat mass $(r=0.54, P=0.002)$. Leptin concentration per kilogram fat mass was positively correlated with insulin $(r=0.40, P=0.03)$.

Conclusions: In contrast to serum concentrations of TNF $\alpha$, serum leptin did not differ from that in controls, implying that leptin is not a major contributor to the previously found increase in cardiovascular morbidity in the hypopituitary women investigated. However, the patients had increased leptin concentrations per unit fat mass, indicating an altered adipocyte secretory function in this group.
\end{abstract}

European Journal of Endocrinology 146 737-742

\section{Introduction}

Adult hypopituitary patients with growth hormone deficiency (GHD) exhibit abnormal body composition, with increased central fat mass $(1,2)$. As abdominal adiposity is a risk factor for cardiovascular disease (3), this could contribute to the enhanced cardiovascular mortality and morbidity observed in hypopituitary patients with untreated GHD (4-6). Leptin circulates in correlation to adiposity $(7,8)$ and is secreted predominantly from subcutaneous fat, but also from visceral fat (9). It was recently indicated that leptin is correlated with cardiovascular diseases (10) and therefore could be a mediating factor for the increased cardiovascular risk in GH-deficient patients. Several studies have in fact shown increased circulating leptin concentrations in GH-deficient patients compared with healthy individuals (11-14). In some of these previous investigations, patients and controls differed in body fat mass (12), or no matching for body mass index (BMI) or fat mass had been performed $(13,14)$, making conclusions hazardous. Thus it is still not established whether GHD is associated with changes in leptin concentrations or whether the increased concentrations found in some studies are simply a result of differences in body fat mass. Furthermore, it is essential that women and men are investigated separately, because of sex-related differences in leptin concentrations $(15,16)$, and this has not always been the case $(13,14)$. In addition, other factors such as circulating insulin $(17,18)$ and oestradiol (19) could also influence leptin concentrations, and these factors might be altered in GHD.

Tumour necrosis factor (TNF) $\alpha$ is another product of adipocytes (20), and serum concentrations of TNF $\alpha$ are 
increased in obese individuals (21). It has been suggested that TNF $\alpha$ has a role in the development of insulin resistance (22), and a relationship between concentrations of TNF $\alpha$ and cardiovascular diseases has been shown (23). TNF $\alpha$ might therefore also be of relevance for patients with GHD, in view of their altered body composition and increased cardiovascular morbidity. A previous study has, indeed, demonstrated increased concentrations of TNF $\alpha$ in patients with GHD, although no matching of body composition was made in that study (24).

The aim of the present study was to clarify whether the adipocyte products, leptin and TNF $\alpha$ are increased in patients with GHD compared with controls with similar fat mass. We therefore assessed leptin and TNF $\alpha$ in a group of hypopituitary women with untreated GHD, who had previously been reported to exhibit increased cardiovascular morbidity(6). We also related leptin and TNF $\alpha$ concentrations to insulin-like growth factor (IGF)-I, insulin and oestradiol concentrations.

\section{Material and methods}

\section{Patients and controls}

The group of GH-deficient patients consisted of 33 women aged 39-77 years (median 64 years) and with hypopituitarism for 6-46 years (median 18 years). Their diagnoses are shown in Table 1. Twentyfive of the patients had received postoperative cranial radiotherapy (median dose $40 \mathrm{~Gy}$ ) at least 5 years before the study. Twenty-five of the patients were adrenocorticotrophic hormone and thyroid-stimulating hormone deficient and were treated with glucocorticoids (cortisone acetate $25-37.5 \mathrm{mg} /$ day) and thyroid hormones (levothyroxine $0.075-0.25 \mathrm{mg} / \mathrm{day}$ ) respectively. Treatment with an antidiuretic hormone analogue (desmopressin $0.1 \mu \mathrm{g} /$ day nasally, or $0.1-0.4 \mathrm{mg} /$ day orally) was given to five patients with diabetes insipidus. Five patients with hyperprolactinaemia were treated with dopamine agonists (bromocriptine or quinagolide hydrochloride). None of the patients had previously been treated with GH.

The patients were compared with 33 controls of the same sex, age, smoking habits (life-long non-smokers, ex-smokers and present smokers) and educational level (6-9 years of elementary school, high school and university education). The controls were randomly

Table 1 Diagnoses of 33 women with hypopituitarism included in the study.

Non-functioning pituitary adenoma

17

Prolactinoma

Craniopharyngioma

Meningioma

Sheehan's postpartum necrosis

Idiopathic hypopituitarism selected from a computerised register comprising the population in the catchment area for the patients (Southern Swedish Medical Region). The 33 patients and controls investigated in this study have previously been studied with respect to differences in incidence of cardiovascular morbidity and prevalence of cardiovascular risk factors; further details of the matching procedure have been presented previously (6).

Serum concentrations of IGF-I and oestradiol in patients and controls are shown in Table 2. Twentynine of the patients had subnormal serum IGF-I concentrations; the other four had normal concentrations, but had previously been found to be $\mathrm{GH}$ deficient as assessed by an insulin tolerance test (peak GH response $<9 \mathrm{mIU} / \mathrm{l}$ ). At the time of the present investigation, two of the patients and six of the controls had normal menses and all gonadotropin-insufficient patients aged 50 years or younger were given sex hormone replacement (conjugated oestrogen plus medroxyprogesterone, oestradiol plus norethisterone acetate, or oestradiol plus levonorgestrel). None of the controls had premature menopause (median age 50 years; range 45-56 years). Six of the patients were treated with sex hormones after the age of 50 years and five control individuals had postmenopausal treatment (oestradiol plus norethisterone acetate or conjugated oestrogen plus medroxyprogesterone). All patients and controls had normal serum creatinine concentrations. Liver enzymes were also in the normal reference range, except in one patient who had slightly increased concentrations.

\section{Body composition}

Body weight was measured after a 12-h fast and body height was measured barefoot. BMI was calculated as $\mathrm{kg} / \mathrm{m}^{2}$. Waist circumference was measured with a soft tape at the level of the umbilicus with the individual in the standing position and hip circumference was measured over the greater trochanters, enabling calculation of the waist:hip ratio (WHR). Body composition was measured with the individual in the supine position, by bioelectric impedance analysis using the BIA 101-S technique (RJL-Systems, Detroit, MI, USA). A $50 \mathrm{KHz}, 800 \mu \mathrm{A}$ current was applied.

\section{Biochemical assays}

Blood samples were drawn in the morning after a 12-h fast and before administration of medication. Serum IGF-I was measured by radioimmunoassay after acidethanol extraction and cryoprecipitation. Truncated IGF-I was used as radioligand to minimize interaction of IGF binding proteins (25). The intra- and interassay coefficients of variation (CVs) were $4 \%$ and $11 \%$ respectively. A reference range for serum IGF-I for patients older than 70 years was obtained from a populationbased study of individuals aged 80 years (26). All seven patients aged 71-77 years had serum IGF-I 
Table 2 Characteristics and serum concentrations of IGF-I and oestradiol in 33 hypopituitary women and 33 healthy control women.

\begin{tabular}{|c|c|c|c|c|c|}
\hline & \multicolumn{2}{|c|}{ Patients } & \multicolumn{2}{|c|}{ Controls } & \multirow[b]{2}{*}{$\boldsymbol{P}$} \\
\hline & Median & Range & Median & Range & \\
\hline Age (years) & 64 & $(39-77)$ & 64 & $(39-77)$ & \\
\hline Height (cm) & 162 & $(153-176)$ & 164 & $(149-175)$ & $>0.5$ \\
\hline Weight (kg) & 68.5 & $(43.7-148.2)$ & 72.7 & $(52.8-113.5)$ & 0.4 \\
\hline BMI $\left(\mathrm{kg} / \mathrm{m}^{2}\right)$ & 25.1 & $(17.3-50.1)$ & 26.7 & $(20.0-42.2)$ & 0.4 \\
\hline Fat mass $(\mathrm{kg}) \dagger$ & 23.0 & $(13.1-66.8)$ & 27.7 & $(14.7-53.9)$ & $>0.5$ \\
\hline Waist $(\mathrm{cm})$ & 89.0 & $(72.0-134.0)$ & 88.0 & $(65.0-115.0)$ & $>0.5$ \\
\hline Waist:hip ratio & 0.87 & $(0.77-1.11)$ & 0.82 & $(0.69-0.95)$ & 0.01 \\
\hline Serum IGF-I ( $\mu \mathrm{g} / \mathrm{I})$ & 62 & $(21-148)$ & 158 & $(89-265)$ & 0.001 \\
\hline Serum oestradiol (pmol/l) & $<70$ & $(<70-1187)$ & $<70$ & $(<70-2442)$ & 0.4 \\
\hline
\end{tabular}

† Measured by bioimpedance analysis. Values are missing in four patients and two controls, because of problems with the bioimpedance analyser.

concentrations less than -2SD of normal 80-year-old individuals. Serum insulin was measured with a competitive radioimmunoassay (27), with intra- and interassay CVs of $7.1 \%$ or less. Serum oestradiol was analysed by a radioimmunological method (Diagnostic Products, Los Angeles, CA, USA), and the intra- and interassay CVs were $15 \%$ or less, with a limit of detection of $70 \mathrm{pmol} / \mathrm{l}$. Serum leptin was analysed with a double-antibody radioimmunoassay using rabbit antihuman leptin antibodies, ${ }^{125}$ I-labelled human leptin as tracer, and human leptin as standard (Linco Res., St Charles, MO, USA) as previously described (28). The interassay $\mathrm{CV}$ was $7 \%$. Serum TNF $\alpha$ was measured by a sandwich enzyme immunoassay technique using a monoclonal antibody specific for $\mathrm{TNF} \alpha$ (Quantikine, R\&D Systems, Minneapolis, MN, USA). The interassay CV was $5 \%$.

\section{Statistical analysis}

Data are presented as the median and range. Patients and controls were compared with the Wilcoxon matched pair, signed rank test. Univariate correlation was assessed using Spearman's rank order correlation test. The level of significance was set at $P<0.05$.

\section{Results}

Body weight, BMI, fat mass and waist circumference were similar in patients and controls (all $P \geq 0.4$ ), however the WHR was greater in the patients $(P=$ 0.01) (Table 2). Serum leptin concentration did not differ significantly between patients and controls (Table 3). However, when leptin concentration was expressed per kilogram fat mass, the patients had significantly greater values $(P=0.01)$. Serum TNF $\alpha$ and TNF $\alpha$ per kilogram fat mass were significantly greater in the patients (both $P=0.001)$. In contrast, there was no significant difference between the groups with respect to serum insulin concentrations.

Serum leptin concentrations correlated positively with BMI $(r=0.37, P=0.03)$ and kilogram fat mass ( $r=0.54, P=0.002)$ in the patients. There were also significant correlations between leptin and BMI $(r=0.66, P=0.001)$ and leptin and kilogram fat mass $(r=0.68, P=0.001)$ in the controls. In the patients, leptin per kilogram fat mass was positively correlated with insulin $(r=0.40, P=0.03)$, but not with IGF-I or oestradiol $(P>0.5)$.

Serum TNF alpha concentration did not correlate with BMI, kilogram fat mass, serum leptin or serum insulin in the patient group (all $P>0.4$ ).

\section{Discussion}

The present study examined the concentrations of the adipocyte-derived humoral factors, leptin and $\mathrm{TNF} \alpha$, in relation to body fat mass in hypopituitary women with GHD, compared with those of a control group with similar fat mass. In previous studies, leptin concen-

Table 3 Serum concentrations of leptin, TNF $\alpha$ and insulin in 33 women with hypopituitarism and 33 matched controls.

\begin{tabular}{|c|c|c|c|c|c|}
\hline & \multicolumn{2}{|c|}{ Patients } & \multicolumn{2}{|c|}{ Controls } & \multirow[b]{2}{*}{$P$} \\
\hline & Median & Range & Median & Range & \\
\hline Leptin (ng/ml) & 17.2 & $(4.9-66.7)$ & 15.7 & $(4.2-44.9)$ & 0.4 \\
\hline Leptin $/ \mathrm{kg}$ fat mass $(\mathrm{ng} / \mathrm{ml}$ per $\mathrm{kg})$ & 0.8 & $(0.4-1.6)$ & 0.6 & $(0.3-0.6)$ & 0.01 \\
\hline $\mathrm{TNF} \alpha(\mathrm{ng} / \mathrm{l})$ & 4.7 & $(0.4-29.7)$ & 2.0 & $(0-7.0)$ & 0.001 \\
\hline $\mathrm{TNF} \alpha / \mathrm{kg}$ fat mass (ng/l per kg) & 0.2 & $(0.02-1.4)$ & 0.09 & $(0-0.2)$ & 0.001 \\
\hline Insulin (m/U/l) & 7 & $(4-32)$ & 9 & $(5-46)$ & 0.3 \\
\hline
\end{tabular}


trations have been shown to be increased in hypopituitary women with GHD compared with healthy controls (12). However, this has been an inconsistent finding $(29,30)$, possibly dependent on whether or not matching had been made for body fat. Thus, in the studies showing similar fat mass in GH-deficient women and controls, no significant difference in leptin has been observed $(29,30)$, whereas an increased fat mass in GH-deficient patients has been associated with increased concentrations of leptin (12). The present study revealed no significant difference in the circulating serum leptin concentrations between women with GHD and a control group with similar fat mass. However, the ratio leptin:kilogram fat, which served as a marker of adipocyte secretory function, was significantly greater in the patients than in controls. One possible explanation for the greater leptin:kilogram fat mass ratio in patients could be that they have a different distribution of fat compared with that in controls, as the WHR was increased in the hypopituitary women, indicating an increased abdominal fat mass. However, it is unlikely that the increase in leptin concentration per unit fat mass in the patients could be explained entirely by increased visceral fat, as it has previously been suggested that the subcutaneous fat, and not the visceral fat, depot is the major source of leptin (9). A potential concern is that the state of hydration influences measurements by the BIA technique (31), and it has previously been shown that the state of hydration is subnormal in GH-deficient patients (32). However, our results are supported by a strong significant correlation between fat mass and leptin, which was of similar degree in controls and in patients, and also similar to that found in previous studies using dual energy X-ray absorptiometry $(12,29)$. Differences between patients and controls with respect to other circulating hormones of importance for the leptin concentrations should also be considered. Oestrogen might be such a factor, as it seems to be a positive regulator of leptin (19), although other studies have reported no independent association between oestrogens and leptin (33). In the present study, however, it is unlikely that oestrogens contributed to the greater leptin concentration per kilogram fat in the patients, as oestrogen concentrations did not differ between patients and controls and the prevalence of postmenopausal sex hormone treatment was similar in the two groups. It should be mentioned that, because the majority of the patients of fertile age were receiving replacement therapy with oestrogen because of gonadotropin insufficiency, it was not possible to analyse separately those individuals not receiving such replacement treatment.

Another tentative factor explaining the greater leptin production in the patients is the GHD per se. The hypopituitary patients had a high probability of GHD, but none had received $\mathrm{GH}$ treatment. Thus 29 of the patients had a serum IGF-I concentration less than the normal range, which is strongly predictive of GHD in patients with pituitary disease (34). The four patients with a normal serum IGF-I concentrations gave a pathological evoked GH response to an insulin tolerance test. A majority of the patients had received irradiation therapy, and had more than two pituitary hormone insufficiencies, which further increases the probability of $\operatorname{GHD}(35,36)$. GH has effects on adipose tissue and stimulates lipolysis (37). Whether GH or IGF-I has direct regulatory abilities with respect to leptin production is, however, not yet established. Interestingly, in GHdeficient children it has been shown that the reduction in serum leptin concentrations after GH treatment occurs independently of changes in BMI (38). Moreover, in hypophysectomized rats, IGF-I treatment suppressed leptin mRNA expression (39), and in a study of GHdeficient patients, administration of IGF-I decreased serum leptin concentrations after only a few days of treatment (40). We found, however, no significant association between IGF-I and leptin in our patients, although an association between biologically active IGF-I and leptin cannot be excluded, as free IGF-I was not measured. Thus further studies are needed to investigate the roles of GH and IGF-I in the regulation of leptin production.

Insulin is a positive regulator of leptin production in healthy individuals $(17,18)$. In the present study, there was also a significant positive relationship between insulin and leptin concentration per kilogram fat in the hypopituitary GH-deficient patients, indicating an important regulatory role for insulin in leptin production in this patient group also. However, insulin concentrations were not different between the patients and the controls and it is therefore unlikely that insulin explains the differences in leptin concentrations per kilogram fat between the groups.

To examine whether another product from the adipocytes is similarly altered, which would point to a more generalised perturbation of adipocyte secretory function, we also analysed $\mathrm{TNF} \alpha$, which is secreted from adipocytes (20). GH administration has been shown to have a modulating effect on the release of TNF $\alpha$ in children with GHD (41). Moreover, TNF $\alpha$ has recently been found to be increased in hypopituitary adult patients with GHD and GH replacement partly reduced this increase (24). We confirmed these findings because, in our study group also, serum concentrations of $\mathrm{TNF} \alpha$ and $\mathrm{TNF} \alpha$ per kilogram fat were greater in patients than in the controls. This is also supported by the previously mentioned study, which showed that the increase in TNF $\alpha$ might be related to increased monocyte production of the cytokine (24). In the present study, there was no significant correlation between fat mass and TNF $\alpha$. Therefore, although production of $\mathrm{TNF} \alpha$ seems to be increased in hypopituitary patients, this may not be true for its production in adipocytes.

Although not proven to be mediating factors, both leptin and TNF $\alpha$ have been associated with atherosclerotic diseases $(10,23)$. Specifically, leptin has been 
suggested to increase blood pressure by an increased sympathoadrenal activity $(42,43)$, whereas $\mathrm{TNF} \alpha$ has been believed to be involved in the pathogenesis of insulin resistance (22). This might be of importance for hypopituitary patients with GHD, who have increased risk of cardiovascular disease (4-6). This study of a well-controlled group of hypopituitary patients with GHD has shown that, whereas the increased cardiovascular risk may be associated with $\mathrm{TNF} \alpha$, it is unlikely that leptin is involved.

\section{References}

1 Snel YEM, Brummer R-JM, Doerga ME, Zelissen PMJ, Bakker CJG, Hendriks MJ et al. Adipose tissue assessed by magnetic resonance imaging in growth hormone-deficient adults: the effect of growth hormone replacement and a comparison with control subjects. American Journal of Clinical Nutrition 199561 1290-1294.

2 Weaver JU, Monson JP, Noonan K, John WG, Edwards A, Evans KA et al. The effect of low dose recombinant human growth hormone replacement on regional fat distribution, insulin sensitivity, and cardiovascular risk factors in hypopituitary adults. Journal of Clinical Endocrinology and Metabolism 199580 153-159.

3 Lamarche B. Abdominal obesity and its metabolic complications: implications on the risk of ischemic heart disease. Coronary Artery Disease $19989473-481$

4 Rosén T \& Bengtsson B-Å. Premature mortality due to cardiovascular disease in hypopituitarism. Lancet 1990336 285-288.

5 Bülow B, Hagmar L, Mikoczy Z, Nordström C-H \& Erfurth EM. Increased cerebrovascular mortality in patients with hypopituitarism. Clinical Endocrinology $1997 \mathbf{4 6} 75-81$.

6 Bülow B, Hagmar L, Eskilsson J \& Erfurth EM. Hypopituitary females have a high incidence of cardiovascular morbidity and increased prevalence of cardiovascular risk factors. Journal of Clinical Endocrinology and Metabolism 200085 574-584.

7 Considine RV, Sinha MK, Heiman ML, Kriauciunas A, Stephens TW, Nyce MR et al. Serum immunoreactive-leptin concentrations in normal-weight and obese humans. New England Journal of Medicine $1996334292-295$.

8 Lönnqvist F, Arner P, Nordfors L \& Schalling M. Overexpression of the obese $(o b)$ gene in adipose tissue of human obese subjects. Nature Medicine 19951 950-953.

9 Van Harmelen V, Reynisdottir S, Eriksson P, Thorne A, Hoffstedt J, Lönnqvist $\mathrm{F}$ et al. Leptin secretion from subcutaneous and visceral adipose tissue in women. Diabetes $1998 \mathbf{4 7} 913-917$.

10 Söderberg S, Ahrén B, Jansson JH, Johnson O, Hallmans G, Asplund $\mathrm{K}$ et al. Leptin is associated with increased risk of myocardial infarction. Journal of Internal Medicine 1999246 409-418.

11 Al-Shoumer KAS, Anyaoku V, Richmond W \& Johnston DG. Elevated leptin concentrations in growth hormone-deficient hypopituitary adults. Clinical Endocrinology 199747 153-159.

12 Fisker S, Vahl N, Hansen TB, Jörgensen JOL, Hagen C, Örskov H et al. Serum leptin is increased in growth hormone-deficient adults: relationship to body composition and effects of placebocontrolled growth hormone therapy for 1 year. Metabolism 1997 $46812-817$.

13 Nyström F, Ekman B, Österlund M, Lindström T, Öhman KP \& Arnqvist HJ. Serum leptin concentrations in a normal population and in GH deficiency: negative correlation with testosterone in men and effects of GH treatment. Clinical Endocrinology 199747 $191-198$.

14 Nörrelund H, Höjbjerg Gravholt C, Englaro P, Blum WF, Rascher W, Christiansen JS et al. Increased levels but preserved diurnal variation of serum leptin in GH-deficient patients: lack of impact of different modes of $\mathrm{GH}$ administration. European Journal of Endocrinology 1998138 644-652.
15 Kennedy A, Gettys TW, Watson P, Wallace P, Ganaway E, Pan Q et al. The metabolic significance of leptin in humans: genderbased differences in relationship to adiposity, insulin sensitivity, and energy expenditure. Journal of Clinical Endocrinology and Metabolism 199782 1293-1300.

16 Saad MF, Damani S, Gingerich RL, Riad-Gabriel MG, Khan A, Boyadjian R et al. Sexual dimorphism in plasma leptin concentration. Journal of Clinical Endocrinology and Metabolism $1997 \mathbf{8 2}$ 579-584.

17 Ahrén B \& Larsson H. Leptin - a regulator of islet function?: its plasma levels correlate with glucagon and insulin secretion in healthy women. Metabolism $1997 \mathbf{4 6} 1477-1481$.

18 Doucet E, St-Pierre S, Almeras N, Mauriege P, Despres JP, Richard $\mathrm{D}$ et al. Fasting insulin levels influence plasma leptin levels independent from the contribution of adiposity: evidence from both a cross-sectional and an intervention study. Journal of Clinical Endocrinology and Metabolism 200085 4231-4237.

19 Shimizu H, Shimomura Y, Nakanishi Y, Futawatari T, Ohtani K, Sato $\mathrm{N}$ et al. Estrogen increases in vivo leptin production in rats and human subjects. Journal of Endocrinology $1997 \quad \mathbf{1 5 4}$ 285-292.

20 Ahima RS \& Flier JS. Adipose tissue as an endocrine organ. Trends in Endocrinology and Metabolism 200011 327-332.

21 Corica F, Allegra A, Corsonello A, Buemi M, Calapai G, Ruello A et al. Relationship between plasma leptin levels and the tumor necrosis factor-alpha system in obese subjects. International Journal of Obesity Related Metabolic Disorders 199923 355-360.

22 Hotamisligil GS. Mechanisms of TNF-alpha induced insulin resistance. Experimental and Clinical Endocrinology and Diabetes 1999 $107119-125$.

23 Mendall MA, Patel P, Asante M, Ballam L, Morris J. Strachan DP et al. Relation of serum cytokine concentrations to cardiovascular risk factors and coronary heart disease. Heart $1997 \mathbf{7 8} 273-277$.

24 Serri O, St-Jacques P, Sartippour M \& Renier G. Alterations of monocyte function in patients with growth hormone (GH) deficiency: effects of substitutive GH therapy. Journal of Clinical Endocrinology and Metabolism $1999 \mathbf{8 4} 58-63$.

25 Bang P, Eriksson U, Sara V, Wivall I-L \& Hall K. Comparison of acid ethanol extraction and acid gel filtration prior to IGF-I and IGF-II radioimmunoassays: improvements of determinations in acid ethanol extracts by the use of truncated IGF-I as radioligand. Acta Endocrinologica $1991 \mathbf{1 2 4} 620-629$.

26 Erfurth EM, Bülow B \& Hagmar L. Serum levels of insulin-like growth factor I (IGF-I) and IGF-binding protein-3 (IGFBP-3) and their relationships with body composition in elderly individuals. Endocrinology and Metabolism 19974 (Suppl B) 175.

27 Thorell JI, Larson SM, In Radioimmunoassay and Related Techniques, pp 205-211. St Louis: CV Mosby Company, 1978.

28 Ma ZA, Gingerich RL, Santiago JV, Klein S, Smith CH \& Landt M. Radioimmunoassay of leptin in human plasma. Clinical Chemistry $199642942-946$.

29 Gill MS, Toogood AA, O’Neill PA, Adams JE, Thorner MO, Shalet SM et al. Relationship between growth hormone (GH) status, serum leptin and body composition in healthy and GH deficient elderly subjects. Clinical Endocrinology 199747 161-167.

30 Miyakawa M, Tsushima T, Murakami H, Isozaki O, Demura H \& Tanaka T. Effect of growth hormone (GH) on serum concentrations of leptin: study in patients with acromegaly and $\mathrm{GH}$ deficiency. Journal of Clinical Endocrinology and Metabolism 1998 $833476-3479$.

31 Berneis K \& Keller U. Bioelectrical impedance analysis during acute changes on extracellular osmolality in man. Clinical Nutrition $200019361-366$.

32 de Boer H, Blok GJ, Voerman HJ, de Vries PMJM \& van der Veen EA. Body composition in adult growth hormone-deficient men assessed by anthropometry and bioimpedance analysis. Journal of Clinical Endocrinology and Metabolism 199275 833-837.

33 Havel PJ, Kasim-Karakas S, Dubuc GR, Mueller W \& Phinney SD. Gender differences in plasma leptin concentrations. Nature Medicine 19962 949-950. 
34 Bates AS, Evans AJ, Jones P \& Clayton RN. Assessment of GH status in adults with GH deficiency using serum growth hormone, serum insulin-like growth factor-I and urinary growth hormone excretion. Clinical Endocrinology $1995 \mathbf{4 2} 425-430$.

35 Littley MD, Shalet SM, Beardwell CG, Ahmed SR, Applegate G \& Sutton ML. Hypopituitarism following external radiotherapy for pituitary tumours in adults. Quarterly Journal of Medicine 1989 262 145-160.

36 Toogood AA, Beardwell CG \& Shalet SM. The severity of growth hormone deficiency in adults with pituitary disease is related to the degree of hypopituitarism. Clinical Endocrinology $1994 \mathbf{4 1}$ 511-516.

37 Raben MS \& Hollenberg CH. Effect of growth hormone on plasma fatty acids. Journal of Clinical Investigation $195938484-488$.

38 Elimam A, Lindgren AC, Norgren S, Kamel A, Skwirut C, Bang P et al. Growth hormone treatment downregulates serum leptin levels in children independent of changes in body mass index. Hormone Research 199952 66-72.

39 Boeni-Schnetzler M, Gosteli-Peter MA, Moritz W, Froesch ER \& Zapf J. Reduced ob mRNA in hypophysectomised rats is not restored by growth hormone $(\mathrm{GH})$, but further suppressed by exogenously administered insulin-like growth factor (IGF) I
Biochemical and Biophysical Research Communications 1996225 296-301.

40 Bianda TL, Glatz Y, Boeni-Schnetzler M, Froesch ER \& Schmid C. Effects of growth hormone (GH) and insulin-like growth factor-I on serum leptin in GH-deficient adults. Diabetologia $1997 \mathbf{4 0}$ $363-364$.

41 Bozzola M, De Amici M, Zecca M, Schimpff RM \& Rapaport R. Modulating effect of human growth hormone on tumour necrosis factor-alpha and interleukin-1 beta. European Journal of Endocrinology 1998138 640-643.

42 Shek EW, Brands MW \& Hall JE. Chronic leptin infusion increases arterial pressure. Hypertension $199831409-414$.

43 Henriksen JH, Holst JJ, Möller S, Andersen UB, Bendtsen F \& Jensen G. Elevated circulating leptin levels in arterial hypertension: relationship to arteriovenous overflow and extraction of leptin. Clinical Science $200099527-534$.

Received 2 May 2001

Accepted 10 September 2001 